\title{
The Effect of the Organizational Communication on Organizat ional Commitment through Job Satisfaction: Focusing on Irre gular Workers
}

\author{
Jae Won Choi, Doctoral Student, Dept. Of Smart Convergence Consulting, Hansung University, 02876, Korea, \\ blackhole94@hanmail.net \\ *Seok Kee Lee, Professor, Dept. of Computer Engineering, Hansung University, 02876, Korea, \\ seelee@hansung.ac.kr \\ Sung yong Chun, Professor, Dept. of Business Administration, Dankook University, 16890, Korea, \\ sychun@dankook.ac.kr \\ *Corresponding Author
}

\begin{abstract}
Due to the rapidly changing economic environment and industrial structure, the propor tion of irregular workers is gradually increasing. This study aims to provide evidence that can $b$ e used to establish HR strategies for irregular workers who have less loyalty or job satisfaction to the organization than regular workers. The result of this study is as follows: First, we verifie $\mathrm{d}$ that a satisfaction of organizational communication perceived by irregular workers had a positi ve effect on job satisfaction and organizational commitment. Second, a job satisfaction of irregula $r$ workers was analyzed to have a positive effect on organizational commitment. Third, a job sati sfaction was found to have a mediating effect in the relationship between organizational commun ication satisfaction and organizational commitment of irregular workers. Theseresults show that $i$ rregular workers also need smooth communication activities like regular workers in order to inc rease their job satisfaction and organizational commitment. Since the improvement of job satisfac tion through smooth organizational communication activities can be an important factor in impro ving organizational immersion, the results of this study can be the basis for establishing an orga nizational communication plan that encompasses both regular and irregular workers. This study has a meaningful implication in that it provided a clue to re-establish the relationship between $t$ he effectiveness of organizational communication and job satisfaction and organizational commitm ent to irregular workers with relatively few studies.
\end{abstract}

Keywords: Irregular Workers, Organizational Communication, Job Satisfaction, Organizational com mitment, Human Resource Management

Received: 09.12.2020 Accepted: 13.01.2021 $\quad$ Published: 07.02.2021

\section{INTRODUCTION}

The increasing trend of irregular workers due to the spread of employment flexibility strategies by companies due to rapid changes in the economic environment and industrial structure is causing various socio-economic problems and conflicts. Irregular workers are generally forced to have less loyalty or job satisfaction than regular workers due to anxiety over employment. As a way to improve this, this study aimed to analyze the effect of irregular workers' organizational communication satisfaction on job satisfaction and organizational commitment. Through this, we aim to improve the organizational effectiveness of irregular workers and provide empirical evidence useful for establishing effective irregular workers HR strategies for achieving corporate goals.

1. Theory and formula

\subsection{Irregular Workers}

There is no clear standard of international unification for the concept of irregular workers, and it can be regarded as the residual concept of regular workers contrasted to regular workers. In Korea, after the IMF crisis, debate on the concept and scope of irregular workers continued. As a result, the concept and scope of irregular workers were confirmed in July 2002 by agreement between labor, management and government in the special positions of the labor, management and government committees. The concept of irregular workers under this agreement was defined as 'temporary workers (temporary workers)', 'short-term workers (part-time workers)', and 'employees (non-standard workers)' in the form of dispatch, service, or calling on the basis of employment type. In addition, the working class, which is unstable and lacks protection from the Labor Standards Act or benefits from various social insurances, is 
defined as a vulnerable working class[1].

\subsection{Organizational Communication}

Organizational communication can be defined as a comprehensive interaction process with internal and external environments that is conducted to achieve organizational goals and achieve sustainable management based on communication and information exchange among members within the organization based on hierarchical order[2]. In addition, meaningful messages or information between social entities within an organization can be shared, and it can be seen as official or unofficial to achieve the organization's goals[3].

\subsection{Job Satisfaction}

Various studies on job satisfaction have long been conducted because members may have positive or negative feelings about the organization, depending on whether they are satisfied in many aspects of their job and the performance of their job, which affect organizational performance. In a study on the effects of emotional exhaustion on job satisfaction of call center counselors, job satisfaction refers to pleasant emotional and emotional satisfaction obtained from evaluations of the job itself and the work environment based on the level of individual values, attitudes, values, desires, beliefs, etc. This affects job performance and expresses satisfaction with the work conditions associated with the job, wages, promotion opportunities, co-workers, bosses, etc[4]. In addition, in a study on the effect of SME employees' communication satisfaction on organizational effectiveness, job satisfaction was defined as an emotional and emotional satisfaction state obtained by evaluating their work environment according to their beliefs, attitudes, and needs[5].

\subsection{Organizational Commitment}

Organizational commitment can also be classified as psychological performance among the evaluation indicators of organizational effectiveness, such as job satisfaction. Organizational commitment is a psychological attachment to the organization to which they belong, and can be defined as the degree to which members of an organization identify themselves with the organization and want to devote to the organization. The more immersed in the organization's work and organization, the more profitable and productivity of the company can be increased[6].

\subsection{A prior study of the relationship between variables}

2.5.1. Relationship between Organizational Communication and Job Satisfaction

A study of hotel employees showed that communication satisfaction, feedback on personal performance, organizational prospects, and media quality among satisfaction of organizational communication had a significant positive effect on job satisfaction. However, it was found that communication with the boss, intra-department, inter-department, and peer-to-peer communication had no significant effect[7].

2.5.2. Relationship between Job Satisfaction and Organizational Commitment

In a study of members of social enterprises, job satisfaction was found to have a significant positive effect on organizational commitment[8]. In a study of airline crew, job satisfaction was found to have a significant positive effect on organizational commitment[9].

2.5.3. Relationship between Organizational Communication and Organizational Commitment

A study of regular workers in Korea and China found that the more active the organizational communication, the more positive the impact on organizational commitment. Further, the detailed elements of organizational communication, upward/downward/horizontal/unofficial communication, have been shown to have a positive effect on organizational commitment, which helps improve organizational commitment and increases members' satisfaction with communication [10].

\section{Experimental setup \\ 3.1. Research Models}

The purpose of this study was to investigate the effect of organizational communication recognized by non-regular workers on organizational commitment through job satisfaction. In order to achieve the research objectives, the research model and hypothesis as shown in Figure 1 were set up.

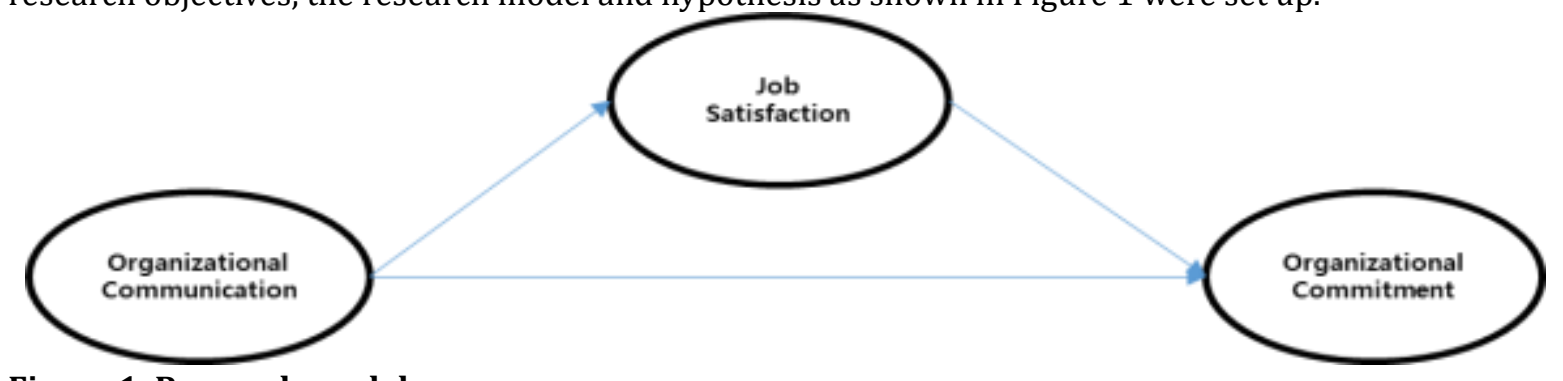

Figure 1. Research model 


\subsection{Hypotheses}

Hypothesis 1: Organizational communication satisfaction of irregular workers will have a positive effect on job satisfaction.

Hypothesis 2: Job satisfaction of irregular workers will have a positive effect on organizational commitment.

Hypothesis 3: Organizational communication satisfaction of irregular workers will have a positive effect on organizational commitment.

Hypothesis 4: Job satisfaction of irregular workers will mediate in the relationship between organizational communication and organizational commitment.

\subsection{Research data and subjects}

In order to confirm the effect of irregular workers' organizational communication satisfaction on job satisfaction and organizational commitment, the 7th Human Capital Enterprise Panel Survey data conducted by the Korea Research Institute for Vocational Education \& Training was used. The subjects of the survey were team leaders, team members, production workers, and service team members, excluding the company's managers and executives, regardless of industry type and size. Of the 10,005 surveys for workers, 163 irregular workers surveys were used for analysis.

\subsection{Operational definition and measurement of variables}

Organizational communication is the exchange of messages through various means in order to form and maintain an activity system for each member in the organization. Or, in the organizational structure, it was defined as sharing messages, ideas, attitudes, etc. through advanced technologies or various means of communication between managers, members, colleagues, or between groups. The questionnaire was composed of three questions: communication between the management, top and bottom, and departments of the company. Job satisfaction is a pleasant emotional and emotional satisfaction level obtained from evaluation of the job itself and the job environment according to the individual's values, needs, and beliefs, and affects job performance. It was defined as an emotional expression representing the degree of satisfaction with the working conditions, such as promotion opportunities, relationships with colleagues and superiors, and working conditions. The questionnaire consisted of three questions: job content, wages, and satisfaction with human relationships. Organizational commitment was defined as the degree to which members of an organization want to identify themselves with the organization and devote themselves to the organization as a psychological attachment to their own organization. The survey consisted of three questions: thinking of myself and the company the same way, feeling lost when changing jobs, and loyalty to the company. The questionnaire was composed on a 5-point scale, with 1 point being measured as 'not at all' and 5 points as 'completely so'.

\section{Result discussions}

\subsection{Empirical analysis result}

4.1.1. Demographic characteristics analysis

The distribution of respondents' industry classification of 96 companies was 58.9 percent for the manufacturing sector, 8 percent for the financial sector, and 33.1 percent for the non-financial sector. The gender was males $86,52.8 \%$, and females $77,47.2 \%$. The union membership rate was $4.3 \%$ with 7 members and $95.7 \%$ with 156 non-members. The final distribution of academic records was 4.9 percent middle school graduates or less, 16 percent humanities high school graduates, 8.6 percent technical high school graduates, 14.7 percent other vocational high school graduates, 21.5 percent junior college graduates, 31.3 percent university graduates, 3.1 percent master's degree graduates.

4.1.2. Validity and reliability analysis

Prior to the hypothesis test, validity and reliability analysis was performed on all items. No factors were eliminated during the factor analysis, and the total variance explained was $71.72 \%$. Variables were named organizational communication, job satisfaction, and organizational commitment. As a result of reliability analysis on them, each factor appeared as a reliable level and all items were used. The value of the Cronbach' $\alpha$ coefficient for each variable was distributed between .742 and .831 . Details are as shown in Table 1.

Table 1: Exploratory Factor Analysis and Reliability Test

\begin{tabular}{l|l|l|l|l}
\hline $\begin{array}{l}\text { Measurement } \\
\text { variables }\end{array}$ & $\begin{array}{l}\text { Organizational } \\
\text { Communication }\end{array}$ & $\begin{array}{l}\text { Job } \\
\text { Satisfaction }\end{array}$ & $\begin{array}{l}\text { Organizational } \\
\text { Commitment }\end{array}$ & C $\alpha$ \\
\hline OCN2 & .864 & & & .831 \\
OCN3 & .800 & & & \\
OCN1 & .779 & .843 & & .793 \\
\hline JS1 & & .818 & & \\
\hline JS3 & & & & \\
\hline
\end{tabular}




\begin{tabular}{l|l|l|l|l}
\hline JS2 & & .658 & & \\
\hline OCT3 & & & .776 & .742 \\
OCT2 & & & .762 & .661 \\
OCT1 & & 2.154 & 1.970 & \\
\hline OV & 2.332 & 23.93 & 21.89 & \\
V\% & 25.91 & 48.84 & 71.72 & \\
AV\% & 25.91 &
\end{tabular}

Annotation 1) OV : Original Value

Annotation 3) AV\% : Accumulation Variance \%

4.1.3. Measurement model analysis

4.1.3.1. Convergent validity analysis

To test the single dimensionality of each measurement variable, a confirmatory factor analysis was performed. The values CMIN/DF (<3.0), GFI, CFI, NFI, IFI( AG0.9), AGFI $(>0.8), \operatorname{RMR}(<0.05)$, and RMSEA(01.0) were used to test the suitability of the data. In order to generate high goodness of fit, the removal process was repeated one by one based on the SMC(Squared Multiple Correlation) value. As a result of analysis after removing job satisfaction 2 and organizational commitment 1 , it was found that all fitness indices satisfied the standard values. All standardized regression coefficients were 0.7 or more, CR was 0.7 or more, and AVE was 0.5 or more, confirming that there was no problem in centralized validity. The detailed results are shown in Table 2 .

Table 2: Confirmatory Factor Analysis and Goodness of Fit of Measurement Model

\begin{tabular}{|c|c|c|c|c|c|c|c|c|}
\hline \multicolumn{2}{|c|}{ Measurement variable } & RW & SRW & SE & $\mathrm{t}$ & SMC & CR & AVE \\
\hline $\begin{array}{l}\text { Organization } \\
\text { al } \\
\text { Communicati } \\
\text { on }\end{array}$ & $\begin{array}{l}\text { OCN1 } \\
\text { OCN2 } \\
\text { OCN3 }\end{array}$ & $\begin{array}{l}.952 \\
1.164 \\
1.000\end{array}$ & $\begin{array}{l}.720 \\
.898 \\
.763\end{array}$ & $\begin{array}{l}.051 \\
.042 \\
.047\end{array}$ & $\begin{array}{l}7.469 \\
3.546 \\
6.904\end{array}$ & .869 & .690 & $\begin{array}{l}.518 \\
.806 \\
.583\end{array}$ \\
\hline $\begin{array}{l}\text { Job } \\
\text { Satisfaction }\end{array}$ & $\begin{array}{l}\text { JS1 } \\
\text { JS3 } \\
\end{array}$ & $\begin{array}{l}1.000 \\
.927\end{array}$ & $\begin{array}{l}.844 \\
.859 \\
\end{array}$ & $\begin{array}{l}.044 \\
.037 \\
\end{array}$ & $\begin{array}{l}4.142 \\
3.748 \\
\end{array}$ & .900 & .818 & $\begin{array}{l}.713 \\
.738 \\
\end{array}$ \\
\hline $\begin{array}{l}\text { Organization } \\
\text { al } \\
\text { Commitment }\end{array}$ & $\begin{array}{l}\text { OCT2 } \\
\text { OCT3 }\end{array}$ & $\begin{array}{l}1.142 \\
1.000\end{array}$ & $\begin{array}{l}.772 \\
.778\end{array}$ & $\begin{array}{l}.063 \\
.048\end{array}$ & $\begin{array}{l}5.327 \\
5.187\end{array}$ & .804 & .673 & $\begin{array}{l}.596 \\
.606\end{array}$ \\
\hline $\begin{array}{l}\text { Measurement } \\
\text { model } \\
\text { Fitness }\end{array}$ & $\begin{array}{l}\text { (initial } \\
\text { AGFI=. } \\
\text { (final } \\
\text { AGFI }=.\end{array}$ & $\begin{array}{l}\text { model) } \\
07, \mathrm{CFI} \\
\text { nodel) } \\
29, \mathrm{CFI}\end{array}$ & $\begin{array}{l}\text { Chi-Sq } \\
.976, \mathrm{~N} \\
\text { Chi-Squ } \\
.988, \mathrm{~N}\end{array}$ & $\begin{array}{l}=39.3 \\
42, \mathrm{IF} \\
17.03 \\
68, \mathrm{IF}\end{array}$ & $\begin{array}{l}f=24, \\
6, \mathrm{RMI} \\
=11, \\
\text { 3, RMR }\end{array}$ & $\begin{array}{l}00, \quad \mathrm{C} \\
3, \mathrm{RM} \\
0, \quad \mathrm{C} \\
8, \mathrm{RMS}\end{array}$ & $\begin{array}{l}\mathrm{DF}=1 . \\
063 \\
\mathrm{~F}=1 . \\
58\end{array}$ & $\begin{array}{l}\text { GFI }=.950, \\
\text { GFI=.972, }\end{array}$ \\
\hline
\end{tabular}

Annotation 1) RW : Regression Weights

Annotation 2) SRW : Standardized Regression Weights

Annotation 3) SE : Standard Error Annotation 4) t : Critical Ratio

Annotation 5) SMC : Squared Multiple Correlation

Annotation 6) CR : Construct Reliability

Annotation 7) AVE : Average variance Extracted

4.1.3.2. Discriminant validity analysis

The results of the model's discriminant validity assessment show that the square value of the correlation coefficient among all variables does not exceed the AVE value, and the results are as shown in Table 3.

Table 3: Validity assessment results of the measurement model

\begin{tabular}{l|l|l|l}
\hline Measurement variable & $\begin{array}{l}\text { Organizational } \\
\text { Communication }\end{array}$ & $\begin{array}{l}\text { Job } \\
\text { Satisfaction }\end{array}$ & $\begin{array}{l}\text { Organizational } \\
\text { Commitment }\end{array}$ \\
\hline $\begin{array}{l}\text { Organizational } \\
\text { Communication }\end{array}$ & .690 & & \\
\hline $\begin{array}{l}\text { Job } \\
\text { Satisfaction }\end{array}$ & .581 & .818 & \\
\hline $\begin{array}{l}\text { Organizational } \\
\text { Commitment }\end{array}$ & .663 & .677 & .673 \\
\hline
\end{tabular}

Annotation) Diagonal dark part is AVE value 


\subsection{Hypothesis test}

The suitability of the structural model is $22=17.035$ ( $\mathrm{p}<.001$ ), TLI=.977, CFI=.988, RMSEA=.058 was found to be satisfactory. As a result of the structural model analysis, it was analyzed that organizational communication had a positive effect on job satisfaction $(\beta=.581, p<.001)$. Job satisfaction was analyzed to have a positive effect on organizational commitment $(\beta=.440, p<.001)$. Organizational communication was analyzed to have a positive effect on organizational commitment $(\beta=.407, p<.001)$. The results of the analysis are shown in Table 4, and the figure is shown in Figure 2.

Table 4. Hypothesis test results

\begin{tabular}{|c|c|c|c|c|c|c|c|}
\hline $\begin{array}{l}\text { Hypoth } \\
\text { esis }\end{array}$ & Path & $\begin{array}{l}\text { Non- } \\
\text { standardization } \\
\text { coefficient }\end{array}$ & $\begin{array}{l}\text { Standardized } \\
\text { coefficients }\end{array}$ & SE & $\mathrm{t}$ & $\begin{array}{l}\text { P- } \\
\text { valu } \\
\text { e }\end{array}$ & Results \\
\hline $\begin{array}{l}\text { Hypoth } \\
\text { esis1 }\end{array}$ & $\begin{array}{l}\text { Organizational } \\
\text { Communication } \\
\rightarrow \quad \text { Job } \\
\text { Satisfaction }\end{array}$ & .581 & .581 & .095 & 6.123 & .000 & $\begin{array}{l}\text { Adopte } \\
\text { d }\end{array}$ \\
\hline $\begin{array}{l}\text { Hypoth } \\
\text { esis } 2\end{array}$ & $\begin{array}{l}\text { Job Satisfaction } \\
\rightarrow \\
\text { Organizational } \\
\text { Commitment } \\
\end{array}$ & .403 & .440 & . 100. & 4.016 & .000 & $\begin{array}{l}\text { Adopte } \\
\text { d }\end{array}$ \\
\hline $\begin{array}{l}\text { Hypoth } \\
\text { esis } 3\end{array}$ & $\begin{array}{l}\text { Organizational } \\
\text { Communication } \\
\overrightarrow{\text { Organizational }} \\
\text { Commitment }\end{array}$ & .373 & .407 & .099 & 3.778 & .000 & $\begin{array}{l}\text { Adopte } \\
\text { d }\end{array}$ \\
\hline \multicolumn{2}{|c|}{ Structure model fit } & \multicolumn{6}{|c|}{$\begin{array}{l}\text { CMIN=17.035, } \quad \mathrm{df}=11, \quad \mathrm{p}=.107, \quad \mathrm{CMIN} / \mathrm{DF}=1.549, \quad \mathrm{TLI}=.977, \\
\mathrm{CFI}=.988, \mathrm{RMR}=.018, \mathrm{GFI}=.972, \mathrm{AGFI}=.929, \mathrm{RMSEA}=.058\end{array}$} \\
\hline
\end{tabular}

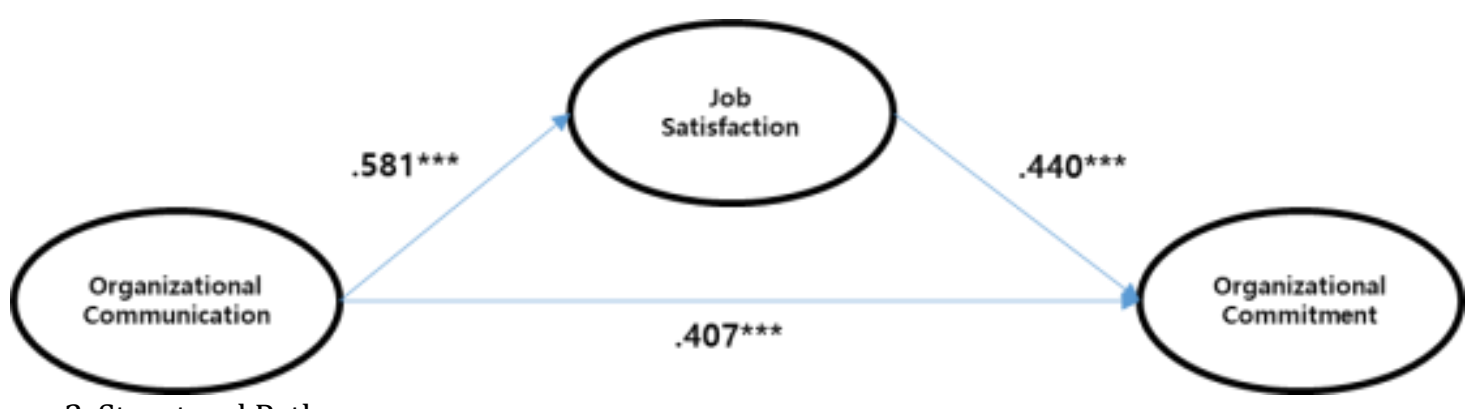

Figure 2. Structural Path

\subsection{Mediated effect analysis}

Whether or not job satisfaction has a mediating effect on the relationship between organizational communication and organizational commitment was analyzed by the bootstrapping method. As a result of the analysis, the partial mediating effect of job satisfaction (.234) was found to be significant, and the analysis results are shown in Table 5.

Table 5. Mediated effect analysis results

\begin{tabular}{l|l|l|l|l}
\hline Hypothesis & Path & $\begin{array}{l}\text { Indirect } \\
\text { effect }\end{array}$ & P-value & Results \\
\hline $\begin{array}{l}\text { Hypothesis } \\
4\end{array}$ & $\begin{array}{l}\text { Organizational Communication } \rightarrow \\
\text { Job Satisfaction } \rightarrow \\
\text { Organizational Commitment }\end{array}$ & .234 & .003 & Adopted \\
\hline
\end{tabular}

\section{Conclusions}

The purpose of this study is to find out that smooth communication with irregular workers within the organization is an important influence factor to improve organizational effectiveness, and thus seek a human resource management plan for irregular workers. The test results of the hypothesis proposed in this study and the implications are as follows. First, it was analyzed that satisfaction of organizational communication (between management, hierarchies, and departments) recognized by irregular workers had a positive effect on job satisfaction. It can be interpreted that the 
management's clear mission and vision for irregular workers, the smooth exchange of opinions between the upper and lower levels and departments, and cooperation have a positive effect on job satisfaction. Second, job satisfaction perceived by irregular workers was analyzed to have a positive effect on organizational commitment. In order to increase the organizational commitment of irregular workers, job satisfaction must be improved. Third, organizational communication recognized by irregular workers was analyzed to have a positive effect on organizational commitment. It can be seen that smooth communication activities are necessary to increase the organizational commitment of irregular workers. Fourth, it was confirmed that job satisfaction plays a partial mediating role in the relationship between irregular workers' organizational communication satisfaction and organizational commitment. These results show that irregular workers also need smooth communication activities like regular workers to improve job satisfaction and organizational commitment. In order to improve job satisfaction of irregular workers, management always shares the company's circumstances, suggests that the organization should avoid disconnection from regular workers and communicate through unified channels. Improved job satisfaction through smooth organizational communication activities can act as an important factor in improving organizational commitment, so the results of this study can be used as a basis for establishing an organizational communication plan that encompasses both regular and irregular workers. If we look at this from the perspective of the manager, we should share the company's mission and vision, and consider introducing various systems so that organizational communication activities can be carried out smoothly. In addition, from the perspective of organizational members, it is necessary to create a cooperative atmosphere through information sharing between members without distinction between regular and irregular workers, and to promote voluntary communication activities through informal group activities. The limitations of this study are: First, the research was conducted by confining the preceding variables that affect organizational effectiveness to organizational communication. Therefore, additional research is needed on various factors such as leadership, education and training, and organizational culture. Second, the actual business performance of companies due to organizational commitment has not been studied. Therefore, it is necessary to examine the relationship between the organization's commitment and actual business performance.

\section{Acknowledgements}

This research was financially supported by Hansung University.

\section{References}

[1] Information on https://www.moel.go.kr

[2] Lim, Young-shin. (2013) The effect or organizational type on organizational commitment : with emphasis on moderating effect of self-leadership. master's thesis, Hanyang University, Korea.

[3] Cheon, Da som. (2020) Effects of Organizational Justice on the Job Satisfaction of Social Workers : Focusing on the Mediating Effects of Organizational Communication. master's thesis, Pusan National University, Korea.

[4] Cho, Sang Eun. (2010) A Study on the Influence of the Customer Orientation and Job Satisfaction as a Result of the Consultant's Emotional Exhaustion at the Call Center. master's thesis, Hoseo University, Korea.

[5] Lee, In-Suk. (2010) The Effect of Communication Satisfaction and Self-directed Learning on Organizational Effectiveness. - Focused on the Mediating Effect of Small Business Manager Coaching Behavior. master's thesis, Hoseo University, Korea.

[6] Park, Cheol-woo. (2017) The Effects of Creative Integration Firm Talent and Labor-Management Partnership on the Organizational Commitment and Non-financial Aptitude of ICT SMEs. Journal of the Korean Entrepreneurship Socieity 12(4), 77-96.

[7] Park, So-Jung. (2016) A Study organizational informal communication effects on organizational commitment and job satisfaction by hotel industry. Tourism Research 41(1), 85-103.

[8] Lee, Yoeng-Taak. (2014) The Impact of Psychological Capital on Job Satisfaction and Organizational Commitment Among Employees of Social Enterprises. Management and Information Studies vol.33, Issue 49, 1-16.

[9] Cho, Kyung-Hee. (2013) The Study of Interdependent Relations among Airlines` Flight Attendants Personal type, Emotional Intelligence, Job Satisfaction, and Organizational Commitment. Tourism Research 38(2), 145-165. 
[10] Li, Jing Jing. (2014) The Effect of the Organizational Communication on Job Satisfaction and Organizational Commitment : Test on the moderating effect of Organizational Trust. Ph. D. Dissertation, Hanbat National University. Korea. 